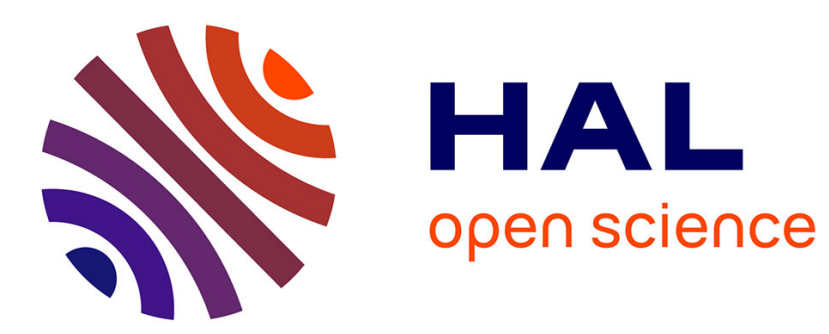

\title{
Fluorescence of Natural DNA: From the Femtosecond to the Nanosecond Time Scales
}

I. Vaya, T. Gustavsson, F.-A. Miannay, Thierry Douki, D. Markovitsi

\section{To cite this version:}

I. Vaya, T. Gustavsson, F.-A. Miannay, Thierry Douki, D. Markovitsi. Fluorescence of Natural DNA: From the Femtosecond to the Nanosecond Time Scales. Journal of the American Chemical Society, 2010, 132 (34), pp.11834-11835. 10.1021/ja102800r . hal-00516393

\section{HAL Id: hal-00516393 \\ https://hal.science/hal-00516393}

Submitted on 10 Sep 2010

HAL is a multi-disciplinary open access archive for the deposit and dissemination of scientific research documents, whether they are published or not. The documents may come from teaching and research institutions in France or abroad, or from public or private research centers.
L'archive ouverte pluridisciplinaire HAL, est destinée au dépôt et à la diffusion de documents scientifiques de niveau recherche, publiés ou non, émanant des établissements d'enseignement et de recherche français ou étrangers, des laboratoires publics ou privés. 


\title{
Fluorescence of natural DNA: from the femtosecond to the nanosecond time-scales
}

\author{
Ignacio Vayá, Thomas Gustavsson, François-Alexandre Miannay, Thierry Douki and Dimitra \\ Markovitsi* \\ Laboratoire Francis Perrin, CEA/DSM/IRAMIS/SPAM - CNRS URA 2453, CEA/Saclay, 91191 Gif-sur-Yvette, France \\ and CEA, INAC, SCIB, UJF \& CNRS, LCIB (UMR_E 3 CEA-UJF and FRE 3200), Laboratoire "Lésions des Acides \\ Nucléiques », 17 Rue des Martyrs, F-38054 Grenoble Cedex 9, France
}

RECEIVED DATE (automatically inserted by publisher); dimitra.markovitsi@cea.fr

The knowledge that absorption of UV radiation by DNA induces photochemical reactions leading to carcinogenic mutations $^{1}$ has triggered numerous studies aiming at the elucidation of the electronically excited states of DNA. ${ }^{2-4}$ In this respect, fluorescence spectroscopy provides valuable information about both the energy of the excited states and their relaxation dynamics. Fluorescence spectra and decays of natural DNA were reported about thirty years ago $^{5}$ but the studies were limited by the time resolution. The first femtosecond investigation of a double-stranded oligomer appeared only in 2003. ${ }^{6}$ Subsequent studies, all concerning synthetic duplexes, revealed important sequence and size effects on the excited states dynamics. ${ }^{3,4,7-9}$ These factors have also a dramatic influence on the fluorescence spectra of model duplexes whose maxima range from 294 to 420 $\mathrm{nm} .^{7,10,11}$ Consequently, the large number of sequences present in natural DNA is expected to give rise to a broad fluorescence, as found in the early studies evoking emission from exciplexes. ${ }^{5}$ More recently, the formation of low-lying excimers/exciplexes in oligomeric duplexes with lifetimes ranging between 5 and 150 ps was deduced from transient absorption measurements, contrasting with the $c a$. 1 ps lifetime of the bright $\pi \pi^{*}$ excited states. ${ }^{3}$

Here we report steady-state fluorescence spectra and fluorescence decays spanning five decades of time obtained for purified genomic calf thymus DNA. We show that the fluorescence spectrum is very similar to that of a stoichiometric mixture of monomeric chromophores. Such a puzzling behavior could be explained by the involvement of dark states, possibly related to charge separation, serving as a reservoir for the repopulation of the bright $\pi \pi^{*}$ excited states.

Decays from the femtosecond to the nanosecond time scales were recorded using a common laser excitation source (150 fs, $267 \mathrm{~nm})$ and two different detection techniques, fluorescence upconversion (FU) and time-correlated single photon counting (TCSPC). A key point in our study was to avoid detecting emission from damaged helices characterized by an excimer like band (Figure SI-2). Experimental protocols consisting of keeping the laser intensity as low as possible, using a sufficiently large ratio of molecules compared to that of the photons absorbed during the measurement and preventing local accumulation of photoproducts were used. ${ }^{12}$ For the same reason, low temperature experiments, very helpful for elucidating complex processes underlying fluorescence decays of multichromophoric systems, are not readily accessible for DNA.

Figure 1 compares the absorption and fluorescence spectra of DNA dissolved in phosphate buffer $\left(0.1 \mathrm{M} \mathrm{NaH}_{2} \mathrm{PO}_{4}, 0.1 \mathrm{M}\right.$ $\mathrm{Na}_{2} \mathrm{HPO}_{4}$ and $0.25 \mathrm{M} \mathrm{NaCl}$ ) and in pure water where base stacking decreases, ${ }^{13}$ leading to an increase of structural disorder. This, in turn, reduces the collective behavior of the FranckCondon states ${ }^{14}$ which is reflected in the weaker bathochromic shift (Figure 1a) and the smaller hypochromism ${ }^{13}$ of the DNA absorption spectrum in pure water compared to that in the buffer. The maxima of both DNA spectra are located at shorter wavelengths than that of a stoichiometric mixture of monomeric nucleotides in water. The latter is composed of $58 \%$ of dAMP and TMP, $42 \%$ of dGMP and dCMP, which corresponds to the ratio of bases in calf thymus DNA. ${ }^{15}$

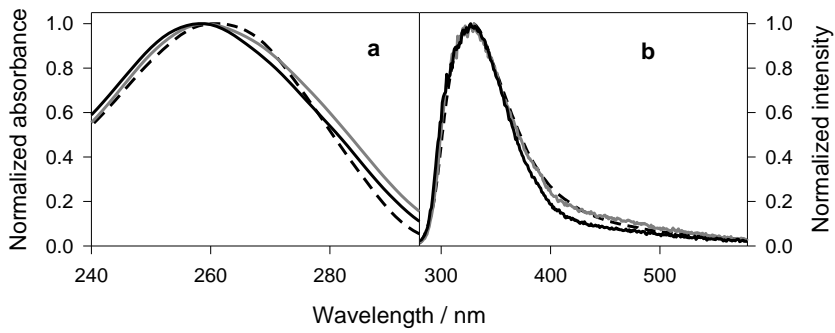

Figure 1. Normalized steady-state absorption (a) and fluorescence (b) spectra of DNA in pure water (grey) and in phosphate buffer (black). Excitation wavelength: $267 \mathrm{~nm}$. The spectra of the stoichiometric mixture of monomers (58\% of dAMP and TMP, $42 \%$ of dGMP and dCMP) in water are shown in dashes.

The main band of the DNA fluorescence spectra peaks at 327 $\mathrm{nm}$ and overlaps perfectly with that of the monomers up to $c a$. $370 \mathrm{~nm}$. The red wing is slightly more intense for DNA in pure water. In the absence of added salts, larger amplitude molecular motions could allow adjacent bases to approach an excimer-like geometry. However, an equally important red wing is observed in the case of the monomers. The fluorescence quantum yield $(\phi)$ of DNA, $(3.1 \pm 0.1) \times 10^{-4}$ in buffer and $(2.8 \pm 0.1) \times 10^{-4}$ in water, is three times higher than that of the nucleotide mixture and similar to that of model helices. ${ }^{7,10}$

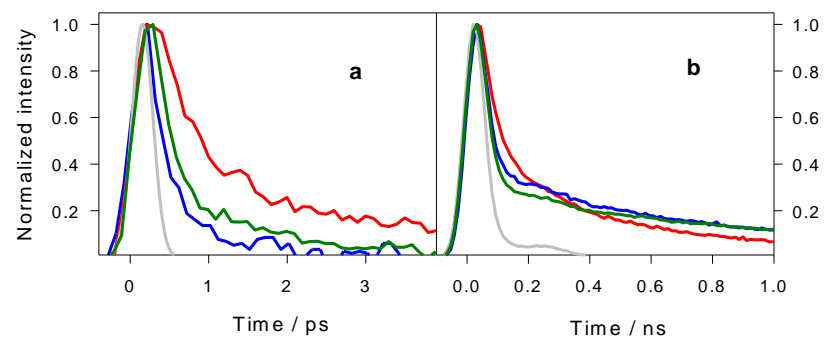

Figure 2. Fluorescence decays of DNA in phosphate buffer recorded at $305 \mathrm{~nm}$ (blue), $330 \mathrm{~nm}$ (green) and $420 \mathrm{~nm}$ (red) by FU (a) and TCSPC (b). The instrumental response functions are shown in grey. 
The fluorescence decays recorded for DNA in buffer solution at 305, 330 and $420 \mathrm{~nm}$ are presented in Figure 2. As observed for model duplexes, ${ }^{16}$ the FU signals become longer with increasing the emission wavelength. A more complex behavior is observed for the TCSPC decays for which the slowest components are relatively more important at shorter wavelengths. A non-linear fitting/deconvolution procedure using multi-exponential functions allowed us to determine the number of photons emitted per decade of time (inset in Figure 2b). We remark that $98 \%$ of the photons are emitted at times longer than $10 \mathrm{ps}$.

A change in the ionic strength does not influence the FU signals, the average lifetime determined at $330 \mathrm{~nm}$ for buffer and pure water solutions being $c a$. 0.4 ps. In contrast, the ionic strength does affect the TCSPC decays which are slower in phosphate buffer than in water (Figure 3). This difference is even more pronounced close to the fluorescence maximum than at 420 $\mathrm{nm}$ where excimers or and exciplexes are supposed to emit.

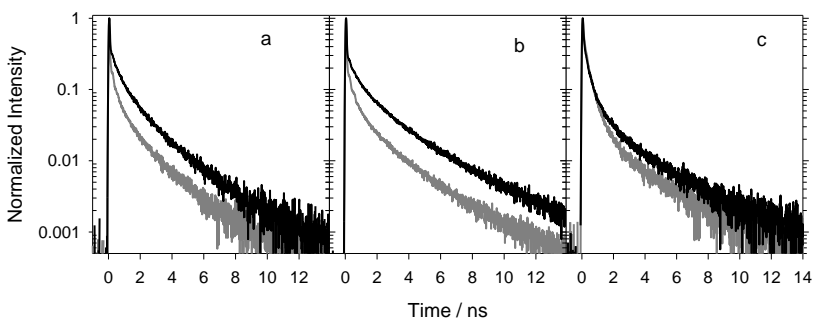

Figure 3. Fluorescence decays of DNA in water (grey) and in phosphate buffer (black) recorded at $305 \mathrm{~nm}$ (a), $330 \mathrm{~nm}$ (b) and $420 \mathrm{~nm}$ (c) by time-correlated single photon counting.

The spectral shape and the wavelength dependence of the TCSPC decays of DNA rule out any noticeable contribution from excimers or exciplexes. Neither can these signals be attributed to the initially populated bright $\pi \pi^{*}$ excited states. The reason is that the lifetime of the bright $\pi \pi^{*}$ within double stranded structures, determined either by FU or by transient absorption does not exceed a few ps. ${ }^{3,17}$ The much longer fluorescence decays reported for model duplexes are associated with emission bands clearly distinguishable from monomer emission, $294 \mathrm{~nm}$ and 420 $\mathrm{nm}$, for alternating guanine-cytosine and adenine-thymine duplexes, respectively. ${ }^{7,9}$ These features have been correlated with interchromophore electronic coupling, which depends on the helix conformation and thus, indirectly, on the sequence. ${ }^{18}$

The paradox of spectrally "monomer like" but long-lived emission of natural DNA can be explained by introducing the notion of a long-lived dark state serving as a reservoir assuring continuous repopulation of the bright states. Thus, even if the lifetimes of the bright monomeric excited states are indeed very short due to internal conversion, they will emit with a lifetime defined by that of the dark state. One important condition would be that the dark state is formed very rapidly with a relatively high yield. Nevertheless, after repopulation of the bright states will still be exposed to important non-radiative deactivation processes, in line with the observed very low fluorescence quantum yield. Note that excitation at $267 \mathrm{~nm}$ corresponds to about $1 \mathrm{eV}$ excess energy with respect to that of the emitting state.

Interestingly, the formation of dark states, attributed to excimers or exciplexes, was proposed in the past on the ground of transient absorption experiments on oligomeric duplexes. ${ }^{19}$ In structurally well ordered stacks, it would not be surprising that separated charges migrate ${ }^{20}$ and get trapped at sites with appropriate redox properties. If the energetics is favorable, charge recombination can occur in the lowest bright $\pi \pi^{*}$ state giving rise to delayed fluorescence, as described for conducting polymers, molecular crystals and nanocrystals. ${ }^{21}$ Regarding DNA, it was shown that charge migration is favored by an increase of the ionic strength, ${ }^{22}$ in line with the shorter lifetimes detected by TCSPC in the absence of salts (Figure 3 ).

The synthetic duplexes whose fluorescence decays were studied so far over several decades of time in connection with their steady-state emission spectrum were composed of just one type of base pairs arranged in a simple sequence, homopolymeric or alternating. The fact that none of them exhibits the puzzling behavior of natural DNA described here suggests that the coexistence of all four bases is necessary for its occurence. Additional studies with model helices having various complex sequences and using different excitation wavelengths will be necessary. Combining results of such studies with the important amount of information accumulated on charge migration and trapping in $\mathrm{DNA}^{23}$ will certainly help to validate our hypothesis of charge separation and charge recombination as a mechanism underlying the long-lived fluorescence in DNA.

Acknowledgment. We thank Dr. Roberto Improta for helpful discussions and the French Agency for Research (ANR PCV07 194999) for financial support.

Supporting Information Available: Experimental details, fits of fluorescence decays.

\section{REFERENCES}

(1) Melnikova, V. O.; Ananthaswamy, H. N. Mutat. Res. 2005, 571, 91-106. (2) Cadet, J.; Vigny, P. In Bioorganic Photochemistry; Morrison, H., Ed.; John Wiley \& Sons: New York, 1990, p 1-272.

(3) Middleton, C. T.; de La Harpe, K.; Su, C.; Law, U. K.; Crespo-Hernández, C. E.; Kohler, B. Ann. Rev. Phys. Chem. 2009, 60, 13-47.

(4) Markovitsi, D.; Gustavsson, T.; Banyasz, A. Mutat. Res. Rev. 2010, 704, 21-28.

(5) Anders, A. Chem. Phys. Lett. 1981, 81, 270-272; Ballini, J. P.; Vigny, P.; Daniels, M. Biophysical Chemistry 1983, 18, 61-65.

(6) Markovitsi, D.; Sharonov, A.; Onidas, D.; Gustavsson, T. ChemPhysChem 2003, 3, 303-305.

(7) Vayá, I.; Miannay, F. A.; Gustavsson, T.; Markovitsi, D. ChemPhysChem 2010, 11, 987-989.

(8) Schwalb, N.; Temps, F. J. Am. Chem. Soc. 2007, 129, 9272-9273; Buchvarov, I.; Wang, Q.; Raytchev, M.; Trifonov, A.; Fiebig, T. Proc. Natl. Acad. Sci. 2007, 104, 4794-4797.

(9) Kwok, W. M.; Ma, C. S.; Phillips, D. L. J. Phys. Chem. B 2009, 113, 11527-11534.

(10) Markovitsi, D.; Gustavsson, T.; Talbot, F. Photochem. \& Photobiol. Sci. 2007, 6, 717-724.

(11) Kwok, W. M.; Ma, C.; Phillips, D. L. J. Am. Chem. Soc. 2008, 130, 51315139.

(12) Markovitsi, D.; Onidas, D.; Talbot, F.; Marguet, S.; Gustavsson, T.; Lazzarotto, E. J. Photochem. Photobiol. A: Chem. 2006, 183, 1-8.

(13) Douki, T. J. Photochem. Photobiol B: Biology 2006, 82, 45-52.

(14) Bittner, E. R. J. Chem. Phys. 2006, 125, 094909 (1-12); Starikov, E. B. Cuniberti, G.; Tanaka, S. J. Phys. Chem. B 2009, 113, 10428-10435; Lange, A. W.; Herbert, J. M. J. Am. Chem. Soc. 2009, 131, 3913-3922; Santoro, F.; Barone, V.; Importa, R. J. Am. Chem. Soc. 2009, 131, 15232-15245.

(15) Matallana-Surget, S.; Meador, J. A.; Joux, F.; Douki, T. Photochem. \& Photobiol. Sci. 2008, 7, 794-801.

(16) Onidas, D.; Gustavsson, T.; Lazzarotto, E.; Markovitsi, D. J. Phys. Chem. B 2007, 111, 9644-9650.

(17) Schwalb, N. K.; Temps, F. Science 2008, 322, 243-245

(18) Lavery, R. et al. Nucl. Ac. Res. 2010, 38, 299-313.

(19) Middelton, C. T.; de La Harpe, K.; Su, C.; Law, U. K.; CrespoHernández, C. E.; Kohler, B. Ann. Rev. Phys. Chem. 2009, 60, 13-47.

(20) Fiebig, T. J. Phys. Chem. B 2009, 113, 9348-9349.

(21) Cichos, F.; von Borczyskowski, C.; Orrit, M. Curr. Opin. Colloid Interface Sci. 2007, 12, 272-284; Romanovskii, Y. V.; Gerhard, A.; Schweitzer, B.; Scherf, U.; Personov, R. I.; Bassler, H. Physical Review Letters 2000, 84, 1027-1030.

(22) Douki, T.; Angelov, D.; Cadet, J. J. Am. Chem. Soc. 2001, 123, 11360 11366.

(23) Beratan, D. N.; Skourtis, S. S.; Balabin, I. A.; Balaeff, A.; Keinan, S.; Venkatramani, R.; Xiao, D. Q. Acc. Chem. Res. 2009, 42, 1669-1678; Kanvah, S.; Joseph, J.; Schuster, G. B.; Barnett, R. N.; Cleveland, C. L.; Landman, U. Acc.Chem. Res. 2010, 43, 280-287; Genereux, J. C.; Barton, J. K. Chem. Rev. 2010, 110, 1642-1662 


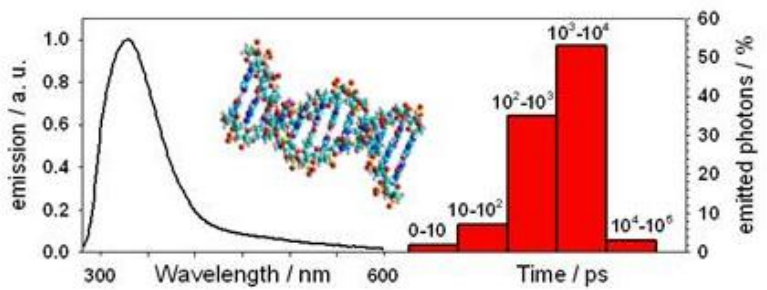

The fluorescence of calf thymus DNA is studied by steady-state and time-resolved spectroscopy combining fluorescence upconversion and time-correlated single photon counting. The fluorescence spectrum is very similar to that of a stoichiometric mixture of monomeric chromophores, arising from bright $\pi \pi^{*}$ states, and contrasts with the existing picture of exciplex emission in natural DNA. Yet, the DNA fluorescence decays span over five decades of time, $98 \%$ of the photons being emitted at times longer than $10 \mathrm{ps}$. These findings, in association with recent studies on model duplexes, are explained by the involvement of dark states, possibly related to charge separation, serving as a reservoir for the repopulation the bright $\pi \pi^{*}$ states. 